УДК 623.974

Фролов С. М., канд. іст. наук

(0000-0001-9873-4413)

Кузовков С. О.

(0000-0002-2324-1187)

Командно-штабний інститут застосування військ (сил) Національного університету оборони України імені Івана Черняховського, Київ

\title{
Удосконалення підготовки військових частин і підрозділів морської компоненти Сил спеціальних операцій Збройних Сил України за досвідом участі в міжнародних навчаннях "SEA-BREEZE" (2018-2019 рр.)
}

Резюме. Розглядаються завдання та способи їх виконання тактичною групою ССО під час проведення міжнародних навчань "SEA-BREEZE" у 2018-2019 рр. та надаються рекомендації щодо удосконалення підготовки військових частин і підрозділів морської компоненти Сил спеціальних операцій Збройних Сил України (далі - ССО ЗС України) у сучасних умовах.

Ключові слова: міжнародні навчання "SEA-BREEZE"; військові частини і підрозділи морської компоненти ССО ЗС України; стандарти НАТО; досягнення сумісності із збройними силами держав-членів HATO

Постановка проблеми. В умовах триваючої збройної агресії Російської Федерації проти України, зокрема, 3 морського напрямку воєнно-політичне керівництво держави змушено переглянути основні керівні документи щодо розвитку ССО 3С України, та приділити більше уваги розвитку іiі морської компоненти щодо удосконалення підготовки до виконання завдань, які виконуються у мирний час та в особливий період [1].

Відсутність достатнього досвіду підготовки та застосування військових частин морської компоненти ССО ЗС України за стандартами НАТО значно знижує їх рівень готовності до виконання завдань та ускладнює досягнення сумісності із аналогічними структурами держав-членів НАТО.

Актуальність теми зумовлена наявністю у складі ССО ЗС України військових частин та підрозділів, які призначені для ведення розвідувально-диверсійних дій 3 морського напрямку та потребують підготовки до застосування за стандартами НАТО.

Аналіз останніх досліджень i публікацій. Про необхідність удосконалення підготовки військових частин та підрозділів морської компоненти ССО ЗС України йдеться як у нормативних документах, так і в публікаціях вітчизняних фахівців [1-6].

У Візії Генерального штабу ЗС України щодо розвитку Збройних Сил України на найближчі 10 років визначені пріоритетні завдання:

переведення штабів на $N, S$ структури;

розроблення та впровадження в усіх сферах діяльності ЗС України стандартів i процедур, прийнятих у державахчленах НАТО;

збільшення кількості підрозділів, які беруть участь у міжнародних навчаннях, коаліційних операціях НАТО;

досягнення високого рівня професійної підготовки особового складу, зокрема шляхом фахового навчання військовослужбовців як в Україні, так і за кордоном;

проходження військової служби на ротаційній основі у штабах НАТО усіх рівнів;

забезпечення інтенсивного навчання військовослужбовців та досягнення ними рівня володіння англійською мовою не нижче CMP-2: $\quad 100 \%$ офіцерського складу, щонайменше $50 \%$ сержантського складу [1].

Відсутність у національному стандарті відповідних методичних рекомендацій 3 планування та участі підрозділів у міжнародних навчаннях не дає змоги їх якісно проводити. Наразі лише в Методичних рекомендаціях 3 підготовки міжнародних (багатонаціональних) військових навчань $\epsilon$ деякі окремі питання 3 порядку проведення міжнародних навчань. Проте цей документ розроблений на підставі стандартів НАТО 2000-х років та виданий у 2007 році, тому не відповідає сучасним вимогам [6]. Зазначений документ потребує переопрацювання 3 урахуванням сучасних стандартів НАТО.

Аналізуючи зазначені джерела варто зазначити, що в Україні у радянський період був накопичений унікальний i вкрай потрібний досвід функціонування військових частин спеціального призначення щодо виконання розвідувально-диверсійних завдань на морі [4]. Однак нині цей досвід, потребує 
врахування стандартів підготовки i застосування держав-членів НАТО.

Для розвитку військових частин та підрозділів морської компоненти ССО ЗС України доцільно використати досвід тактичної групи ССО під час проведення міжнародних навчань "SEA-BREEZE" у 2018 2019 pp.

Метою статті є висвітлення досвіду участі тактичної групи ССО в міжнародних навчаннях “SEA-BREEZE” у 2018-2019 рр. та на підставі цього досвіду надання рекомендації для подальшого удосконалення підготовки військових частин і підрозділів морської компоненти ССО ЗС України.

Виклад основного матеріалу. Аналіз бойового досвіду застосування підрозділів спеціального призначення ЗС України під час антитерористичної операції (АТО), операції Об'єднаних сил (ООС) засвідчив те, що підрозділи, які брали участь у міжнародних навчаннях до початку збройної агресії Російської Федерації, були краще підготовлені та мали найменшу кількість втрат [7]. Цей чинник зумовлює приділити увагу вивченню досвіду міжнародних навчань, які проводяться за стандартами НАТО.

Як відомо, двосторонні навчання "SEABREEZE", традиційно проводяться iз запрошенням представників флотів інших країн за програмою "Партнерство заради миру” відповідно до програми двостороннього співробітництва між Міністерствами оборони України та США [8]. 3 кожним роком спостерігається збільшення кількості країнучасниць, разом 3 цім зростає кількість сил і засобів. Це свідчить про зацікавленість країн НАТО співпрацювати 3 Україною та запозичити величезний досвід, набутий ЗС України під час проведення ООС (АТО).

З 2018 року ССО ЗС України активно беруть участь у навчаннях "SEA-BREEZE" [9]. Так, під час проведення навчань "SEABREEZE-2018" вперше було створено міжнародну тактичну групу ССО, до складу якої входили: штаб групи, 2 групи спеціального призначення, група бойового забезпечення, ланка плавзасобів, та ланка вертольотів. Ця структура була більш оптимальною ніж у ССО ЗС України, оскільки давала змогу тактичній групі спеціальних операцій виконувати завдання самостійно, а не у складі військової частини. Відмінністю складу тактичної групи від національного складу загону $\epsilon$ те, що вона може діяти автономно. До складу групи входять різні засоби доставки (надводний, підводний повітряний i наземний). Це надає значні переваги щодо можливості виводу груп різними засобами доставки. Штаб тактичної групи зазвичай має у своєму складі від 25 до 35 осіб. Структура штабу за секціями: N1 (персонал), N2 (розвідка), N3 (відділ планування), N4 (логістика), N6 (зв'язок) дає змогу своєчасно спланувати та визначити завдання для підпорядкованих підрозділів, забезпечити їм належну підтримку та підвищити їх живучість під час застосування [10].

Для порівняння слід зазначити, що штаб загону ССО ЗС України зазвичай складається 3 двох осіб, і до складу загону не входять ланка вертольотів, плавзасобів та інші засоби доставки. Відповідно, рівень підготовки до планування та ефективність застосування військових частин морської компоненти ССО 3С України значно нижче за аналогічні структури держав-членів НАТО.

До складу штабу тактичної групи ССО на навчаннях 2018 року входили представники 3 України, США, Болгарії, Естонії, Литви, Данії.

Основними завданнями, що покладалися на штаб були:

відпрацювання процедур прийняття рішення та відпрацювання бойових наказів на всіх рівнях відповідно до стандартів НАТО;

управління діями підпорядкованих груп спеціального призначення;

синхронізація роботи штабу тактичної групи спеціального призначення 3 штабами морського компоненту (підрозділами видів/родів військ) на усіх рівнях.

Для груп спеціального призначення були визначені такі завдання:

ведення спеціальної розвідки під час забезпечення морської десантної операції;

проникнення підводним шляхом на військово-морську базу противника 3 подальшим проведенням спеціальних дій;

участь в абордажних і доглядових діях у взаємодії з іншими підрозділами;

відпрацювання ближнього бою в умовах замкнутого простору (англ. $C Q B-$ Close Quarter Battle) [11];

підготовка морського узбережжя для висадки морського десанту.

Для досягнення мети поставлених завдань групам були визначені способи їх виконання, частина 3 яких відпрацьовувалась уперше:

десантування особового складу групи за допомогою комплекту безпарашутного обладнання КАНАТ-1 [11], на землю із 
повним спорядженням, i на обмежені площадки (баржі) на морі, а також спуск особового складу груп за допомогою спускового роликового пристрою на середній десантний корабель “Юрій Олефіренко” відпрацьовувалось уперше;

морські дії 3 абордажної та доглядової тематики (англ. VBSS - Visit, Board, Search, and Seizure) [11] - відпрацьовувалось уперше;

проведення заходів морської навігації на великі відстані на швидкісних гумових човнах у відкритому морі;

вивід водолазів-розвідників підводним шляхом на великі відстані 3 виходом на об'єкт, із подальшим його знищенням;

проведення підводної диверсії визначеного об'єкта, зокрема, підводне мінування військового корабля, та його умовне знищення;

ведення розвідки на узбережжі;

проведення підводних підривних робіт; евакуація групи комбінованим способом, вертольотом та на гумових човнах; десантування групи спеціального призначення 3 гумовим човном 3 вертольоту Mi-8 - відпрацьовувалось уперше.

Виконання завдань зазначеними способами надали практичні вміння групам спеціального призначення морської компоненти ССО ЗС України. Цей досвід був урахований на навчаннях "SEA-BREEZE2019”, коли під час виконання завдань були застосовані такі нові способи, як евакуація особового складу 3 води за допомогою системи КАНАТ-1 та доставка важливого вантажу за допомогою вертольоту Mi-8 на рухомий корабель. Слід зазначити, що планування застосування тактичної групи CCO в навчаннях "SEA-BREEZE-2019" здійснювалось вже за стандартами НАТО.

За успішне виконання завдань під час навчань військові частини та підрозділи морської компоненти ССО ЗС України отримали високі оцінки від своїх іноземних колег із Північноатлантичного Альянсу [12].

Проведений аналіз досвіду міжнародних навчань дав змогу визначити такі основні напрями розвитку військових частин та підрозділів морської компоненти ССО 3С України: планувати за процедурами стандартів НАТО, проводити абордажні та доглядові дії, виводити групи спеціального призначення всіма способами (повітряний, наземний, надводний та підводний).

Оволодіння зазначеними вміннями дасть змогу ефективно взаємодіяти 3 аналогічними структурами ССО держав-членів НАТО та досягнути 3 ними сумісності. Для цього у штабах військових частин та підрозділів морської компоненти ССО ЗС України пропонується започаткувати курси 3 вивчення процедур планування та 3 вивчення іноземної мови (рекомендований рівень СМР-2).

За досвідом навчань встановлено, що для організації взаємодії 3 частинами i підрозділами Військово-Морських Сил (ВМС) 3С України потрібно мати офіцера зі взаємодії, який входить до складу тактичної групи ССО. Так, пропонується передбачити зазначену посаду під час участі військових частин та підрозділів морської компоненти CCO 3С України у спільних операціях (бойових діях) з ВМС ЗС України. Це значно скоротить час на планування та підвищить живучість тактичної групи ССО.

Для якісного планування застосування військових частин та підрозділів морської компоненти ССО 3С України пропонується відпрацювати Методичні рекомендації 3 порядку проведення міжнародних навчань 3 урахуванням сучасних стандартів НАТО.

Висновок. Отже, участь військових частин та підрозділів морської компоненти CCO 3С України у міжнародних навчаннях "SEA-BREEZE" у 2018-2019 рр. дала змогу удосконалити підготовку військових частин та підрозділів морської компоненти ССО ЗС України. Так, було здійснено обмін досвідом та досягнуто певного рівня сумісності із збройними силами держав-членів НАТО, зокрема, штабом - вміння швидко і ефективно планувати застосування сил i засобів за єдиними стандартами 3 партнерами НАТО, а особовим складом бойових груп - набуття необхідного рівня вмінь виконувати завдання визначеними способами.

Для удосконалення підготовки військових частин та підрозділів морської компоненти ССО 3С України під час участі у міжнародних навчаннях і застосуванні в ООС пропонується позитивний досвід цих навчань включити до Методичних рекомендації 3 порядку проведення міжнародних навчань.

Для подальших досліджень розвитку військових частин та підрозділів морської компоненти ССО 3С України пропонується розглянути можливість проведення у Чорному та Азовському морях оглядових операцій за класифікацію керівних документів НАТО із безпосереднім залученням підрозділів ССО та ВMC 3С України у складі доглядових (абордажно-штурмових) команд. 


\section{СПИСОК ВИКОРИСТАНОЇ ЛІТЕРАТУРИ}

1. Про рішення Ради національної безпеки і оборони України від 2 вересня 2015 року "Про нову редакцію Воєнної доктрини України" : Указ Президента України від 24.09.2015 р. №555/2015.

2. Про рішення Ради національної безпеки і оборони України від 20 травня 2016 року "Про Стратегічний оборонний бюлетень України” : Указ Президента України від 06.06.2016 р. № 240/2016.

3. Візія Генерального штабу ЗС України щодо розвитку Збройних Сил України на найближчі 10 років. URL: https://www.mil.gov.ua/news/2020/01/11/ viziya-generalnogo-shtabu-zs-ukraini-shhodo-rozvitkuzbrojnih-sil-ukraini-na-najblizhchi-10-rokiv/ (дата звернення: 04.03.2020).

4. Фролов С. М. Створення та розвиток частин спеціального призначення розвідки Чорноморського флоту (1953 - 1992 рр.) : дис. ... канд. іст. наук : 20.02.22. Київ, 2018. 289 с.

5. Слюсаренко А. В. Творення і застосування компонента сил спеціальних операцій (друга половна XX - початок XXI ст.): дис. ... доктор. іст. наук : 20.02.22. Львів, 2019. 563 с.
6. Методичні рекомендації з підготовки міжнародних (багатонаціональних) військових навчань за участю підрозділів (військовослужбовців) Збройних Сил України, 14.09.2007. № 13550. $30 \mathrm{c}$.

7. Біла книга антитерористичної операції на сході України (2014 - 2016 рр.). Київ : МО України, 2017. $163 \mathrm{c}$.

8. Партнерство заради миру. URL: /https://zakon.rada.gov.ua/ laws/show/950_001 (дата звернення: 04.03.2020).

9. “Сi Бриз-2018”: навчання за умов напруженості в Чорному й Азовському морях. URL: https://www.radiosvoboda.org/a/29353282.html (дата звернення: 06.03.2020).

10. Статут оперативної групи сил спеціальних операцій. Штаб ВГК ОЗС НАТО в Европі. Бельгія, 2015. $224 \mathrm{c}$

11. ААР-6 Словник термінів і визначень НАТО. 2014. $357 \mathrm{c}$.

12. Командувач флоту ВМС США підсумувала “Ci Бриз-2019”. URL: https://www.mil.gov.ua/news/ 2019/07/15/komanduvach-flotu-vms-ssha-pidsumuvalasi-briz-2019/ (дата звернення: 06.03.2020).

Стаття надійшла до редакційної колегії 13.05.2020

\section{The enhancement preparing of the UAF SOF military units and maritime component taking into account the experience gained in the Sea Breeze international exercise (2018-2019)}

\section{Annotation}

In the context of the ongoing armed aggression of the Russian Federation against Ukraine, in particular, from the naval direction, the military-political leadership of the state is forced to revise the main guidelines for the development of the Special Operations Forces (SSO) of the Armed Forces of Ukraine and pay more attention to which are performed in peacetime and in the "Special Period".

The lack of sufficient experience in the training and deployment of naval components of the Special Operations Forces of the Armed Forces of Ukraine according to NATO standards significantly reduces their level of readiness and makes it difficult to achieve compatibility with similar structures of NATO member states.

The urgency of this topic is due to the presence in the Special Operations Forces of the Armed Forces of Ukraine of military units and units that are designed to conduct reconnaissance and sabotage operations in the naval direction and require training for use according to NATO standards.

The purpose of the article is to highlight the experience of participation of the tactical group of Special Operations Forces of the Armed Forces of Ukraine in the international exercises "Sea-Breeze" in 2018-2019. Base on this experience providing recommendations for further improvement of training of military units and subdivisions of the naval component of the Special Operations Forces of the Armed Forces of Ukraine.

To improve the training of military units and units of the naval component of the Special Operations Forces of the Armed Forces of Ukraine during participation in international exercises and application during the Joint Forces Operation, it is proposed to include the positive experience of these exercises in the Guidelines for International Exercises.

Keywords: "Sea-Breeze" International Exercises; military units and subdivisions of the maritime component of the SOFAF of Ukraine; NATO standards; achievement of compatibility with the armed forces of the member states of NATO. 